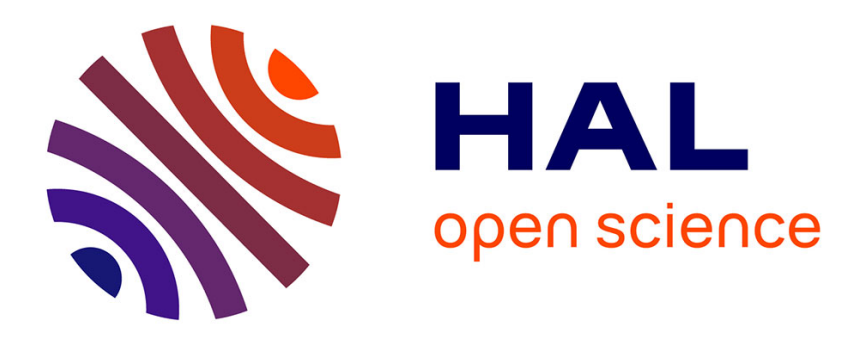

\title{
Urban transport: changes in expertise in France in the 1970s and 1980s
}

Pierre Lassave, Jean-Marc Offner

\section{To cite this version:}

Pierre Lassave, Jean-Marc Offner. Urban transport: changes in expertise in France in the 1970s and 1980s. Transport Reviews, 1989, 9 (2), pp. 119-134. hal-00268989

\section{HAL Id: hal-00268989 \\ https://hal.science/hal-00268989}

Submitted on 2 Apr 2008

HAL is a multi-disciplinary open access archive for the deposit and dissemination of scientific research documents, whether they are published or not. The documents may come from teaching and research institutions in France or abroad, or from public or private research centers.
L'archive ouverte pluridisciplinaire HAL, est destinée au dépôt et à la diffusion de documents scientifiques de niveau recherche, publiés ou non, émanant des établissements d'enseignement et de recherche français ou étrangers, des laboratoires publics ou privés. 


\title{
Urban transport: changes in expertise in France in the 1970s and 1980s
}

\author{
By P. LASSAVE \\ Urban Transport Research Centre, \\ Ministry of Town Planning, Housing and Transport, Bagneux, France \\ and J. M. OfFNER \\ National Institute for Transport and Safety Research, \\ Arcueil, France
}

\begin{abstract}
Analysing changes in the professional environment of experts in urban transport throws light on the evolution and aims of planning in France. Here the 1970s were characterized by active town planning combined with revival of public transport. New ways of appraising the restructuring of networks and of towns evolved under the influence in particular of experts who acted as intermediaries on social and economic factors involved in local decision-making.

These experts had dual professional loyalties, central and local. They drew their cultural basis as much from the technocratic rationalism of immediate post-war economic planning as from the libertarian and ecological social movements of the 1970s. The theory of democratic, decentralized and contractual planning which took shape during the 1970s was institutionalized in the 1980s in the form of the Urban Travel Plans. However, this took place in the context of deregulation and illustrates the ambiguous environment of the experts.
\end{abstract}

\section{Introduction}

It has always been known that there is a difference between knowing how to do something and actually doing it. At the heart of this difference between theory and practice lies expertise, defined as specialized professional know-how upstream of the decision-making process.

In the case of public policies such as urban transport planning, this expertise is subject to criticism, namely, that it is too technocratic, and that it tends to treat the overall policy as subordinate, while ignoring the views of the general public. Expertise in the field of urban transport has therefore undergone profound change over the last two decades, at the same time as the stakes involved in this sector were also undergoing change.

There are at least three good reasons for analysing these changes in expertise. In sociological terms, this paper helps to shed light on the ways in which new professional identities emerge. Through changes in the institutional framework and its related concepts, expertise has developed to take into account synthetically all the upheaval in the urban transport sector. Finally, it offers a vision of the future, by emphasizing the most important aspects of the current method of managing urban transport systems.

Taking a simplified view of the recent history of urban transport, two types of expertise have been seen. The first, in the public transport revival period of $1972 / 74$, was preceded by a profound change in the institutional framework of town planning. The second was in the 1983/84 period, following the law on the future of internal transport (LOTI) and the accelerated rate of decentralization with its transfer of powers to 
provincial authorities, which all occurred against a background of economic crisis and deregulation.

The first period saw a genuine growth of local expertise in urban transport, differing from what had gone before through its intellectual references, its consideration of general policy and technical feasibility, its local involvement and its understanding of the idea of a public service. The second period - now-is more ambiguous. The people involved have changed little; it is they who established the present doctrines and methods. However, the new economic and political situation, combined with technological innovations, would appear to be causing a change in their role.

Table 1. Acronyms used in this article.

\begin{tabular}{ll}
\hline ATEC & Association pour les Techniques du Transport, de l'Environnement et de la \\
& Circulation (Association for the Development of Transport, Environment \\
and Traffic Techniques). Established in 1974, this is an (inter)national & professional association. It publishes a monthly review TEC. \\
& Centre d'Etudes Techniques de l'Equipement (Regional Technical Research \\
CETE & Centre). \\
FPT & Fonction Publique Territoriale (Local Public Offices). \\
GART & Groupement des Autorités Responsables de Transport (Association of \\
& Transport Authorities). Established in 1981, this national association \\
& includes almost all the elected representatives of local authorities responsible \\
for the organization of public passenger transport. \\
LOTI & Loi d'Orientation des Transports Intérieurs (Law on the future of internal \\
transport). \\
POMA 2000
\end{tabular}

\section{The 1970s: homogeneous expertise at the service of social mediation}

\subsection{The urban transport crisis at the end of the $1960 \mathrm{~s}$ and its remedies}

\subsubsection{Situation of public transport}

In the 1960 s, government policy in the matter of urban transport was based on the view that, in the long term, the private car would become the only viable method of travel. This view was reflected in the huge programme of road investments in urban areas, with the construction of ring roads and inner city expressways. However, this strategy came to an abrupt end at the end of the 1960s, when it became clear that the amount of government finance available would be insufficient and that public transport was indispensable for the smooth operation of the urban system. At the same time, hopes for an improved quality of life also became apparent, particularly following the student revolt of May 1968.

Until 1971, nevertheless, public transport systems in the provinces continued to deteriorate: the number of users decreased, investments were insufficient, and they became less attractive. In the Paris area, this process had been partly attenuated by the 
sheer size of the network and, in addition, strong increases in the level of complaints, passed on by the left-wing parties in parliament, had acted as a warning as early as 1969 . Official awareness of the problem came in 1970, a year during which the Ministry of Transport organized a conference on public transport. The government decided to take over the job of updating and enlarging the urban transport profession. Some locally elected representatives also played a leading role on an individual basis.

There had already been numerous projects for new methods of transport which, for a while had appeared to offer a solution. These various technologies, generally based on the idea of small, automatically guided vehicles, nevertheless proved to be unworkable. Proposed by engineers, these projects came up against the complexities of local urban environments, both from the town-planning and institutional viewpoints. There were some exceptions, but we had to wait until the 1980s to see the VAL (automatic metro) brought into service in Lille and the POMA 2000 in Laon.

\subsubsection{Innovations}

The urban transport crisis was overcome largely by innovations in organization. Firstly, the contractual relations between public transport companies and local authorities were changed, with the latter generally taking over ownership of the networks. This was followed by the introduction of transport contributions, a tax paid by employers, which were based on the number of employees and designed to help finance public transport (le versement-transport). This was first introduced in the Paris area in 1971 and was later extended to towns with populations of 300000 and 100000 in 1973 and 1974, respectively. Before this tax was created, public transport was exclusively financed by users. By 1988 the tax was financing an average of $30 \%$ of the costs (users: $45 \%$; local governments: $25 \%$ ).

Other innovations followed that were also more organizational than technical: the carte orange (a monthly season ticket created mainly on the initiative of RATP and the central government) and interconnections between the Paris metro and the RER. Furthermore, the local elected representative, the authorities and the technician were joined by another interested party - the user. An increasing number of associations concerned with protection of the environment were formed. At the same time, the public transport operators sought to expand beyond their restrictive role of simple vehicle operators. They rediscovered the client and moved from their protected universe into the compettitive world (with the search for different methods of transport). The world of marketing also entered the field of public transport.

Urban transport policies in the 1970s can be analysed as local takeovers of national procedures. When the institutional and conceptual instruments proposed were too marked by central government considerations, their application remained a dead letter. This was the case for the Preliminary Studies of Transport Infrastructures (medium-term land-use planning) and the Files on Built-up areas (overall financial forecasts), insufficiently relevant in practice to be of interest to local authorities (cf. table 2).

On the other hand, the Traffic Plans definitely met with success, particularly that concerning the experience of Besançon, where private motor traffic in the town centre was restricted, shopping streets were turned into pedestrian precincts, and the public transport system was restructured. Although they were initially designed as urgent measures in favour of motor cars, while awaiting the completion of new infrastructures, these Traffic Plans rapidly became the main bases for the organization of traffic movements in an urban environment throughout the 1970s. This procedure greatly 
Table 2. Extent of application by local authorities.

\begin{tabular}{ll}
\hline \multicolumn{1}{c}{ Central procedures } & $\begin{array}{l}\text { Application by } \\
\text { local authorities }\end{array}$ \\
\hline Land Use Law (1967) & \\
Three technical levels for urban transport planning (1972) \\
Long-term land-use scheme (30 years) & Low \\
Medium-term land-use scheme (15 years) & Medium \\
Short-term land-use scheme (5-10 years) & Medium \\
'Traffic Plans' (5 years) & High \\
& 300 towns consent to TP \\
& $(1972-1982)$ \\
Contractual policies (since mid-seventies) & High \\
Medium-sized towns urban planning & Medium \\
Public transport development & \\
\hline
\end{tabular}

contributed to the municipal takeover of urban transport matters, with the lead being taken by provincial towns rather than by the large cities.

When Development Contrasts were signed between public transport organizing authorities and the Ministry of Transport, these mainly concerned a fairly limited or linear approach to the networks, by the linking and extension of routes. These transport authorities are sometimes municipalities but more often groupings of towns (communautés urbaines, districts, syndicats intercommunaux).

The technical and policy speeches of the time emphasized three main themes: quantitative development of public transport, protection of town centres against the invasion of private motor vechicle, consideration of non-motorized methods of transport (pedestrians and bicycles) and of specific social groups (children, the elderly and the handicapped).

\subsection{An original professional environment}

\subsubsection{Traditional expertise and the foundations of the new local expertise}

Until the end of the 1960s, national expertise in the matter of urban transport was essentially provided by decentralized government bodies. Those involved were mainly from the State technical organizations, particularly the Highway Engineers. Locally, the public transport companies had no more expertise than the municipal technical services, which were occupied with other operational tasks. The only assistance available to the government came from a number of consulting engineering practices affiliated to several major semi-public and private engineering groups.

The situation was very different where economic planning was concerned. Immediately after the second world war, several organizations had been established with a high level of socio-economic expertise: the National Plan Commission, the National Institute of Statistics, the National Institute of Demographic Studies; followed by the Consumer Research Centre and the National Development Corporation. The authorities gained experience of the contributions made by the social sciences.

Rapid post-war urban growth also compelled the government to encourage research into urban problems. This government-backed urban research led to numerous university-based and private sector teams being set up in the 1960 s. In this 
general movement, the beginning of the 1970s saw the establishment of the Organisation for Thematic Socio-Economic Action in the Transport Field, which contributed to maintaining and widening an intellectual circle concentrating on urban matters within the central administration or on its fringe. Local governments however, did not feel concerned with this research.

It was also at the beginning of the 1970 s that the various institutions provided for under the Land-Use Law of December 1967 were established. Pursuing the policy initiated by the merger of the Ministries of Construction and Public Works, this law provided town planning with the means to exist by standardizing town-planning and development documents. Two new types of body appeared: the Town Planning Agencies, which were inter-community establishments bringing together central government and local authorities on their management boards; and the seven Regional Technical Research Centres (CETE), which were non-governmental organisations making their expertise available to the local authorities in their regions and responsible for playing a leading role in the matter of methodological innovation.

\subsubsection{Characteristics of the new local experts}

Excluding the special case of the Paris region, about 200 local experts in urban transport now provide this new expertise resulting from the reforms carried through at the end of the 1960s and the early 1970s. They are employed in the Town Planning Agencies, the CETEs and in some departments (Marketing, Development, Projects) of public transport companies. In spite of the variety of responsibilities and organizations, these experts form a compact professional group. In the majority of cases, their professional careers are spent in the above three organizations which, particularly in the case of management functions, were originally staffed with people freed by the reduction of the activities of the semi-public and private consulting engineering practices at the beginning of the 1970s. From a professional and intellectual viewpoint, they represent an original mixture of engineering and human sciences. A third of them were trained in economics, geography and management, but have acquired their technical knowledge of public transport on the job. The remainder are engineers, but most have received a grounding in the social sciences.

In terms of social category, they have all the characteristics of the new middle class consisting mainly of salaried employees in the enlarged public sector, in which are included the variotis private organizations fulfilling public service tasks (with or without concessionary rights). It is worth noting that, compared to other sectors involved in development work, very few of these experts are self-employed. These salaried employees tend to be cultured individuals and their professional and private lives overlap to some extent.

They are, above all, the initial intermediaries between the public and private sectors. The public transport sector forms part of a controlled economy which involves central government, local authorities and private companies. By the ambiguity involved in serving both the public and private sectors (public transport companies may be private firms, mixed-economy firms or public bodies; the Town Planning Agencies fulfil a public service but are subject to private law; the CETEs are a central government service but most of their technical staff are not civil servants) and by their compact organization, these experts ensure consistent relations between the private and public sectors.

They are also intermediaries between the local and national authorities. They fully understand the local dimension of problems, not because they are locals born and bred 
but because of the knowledge gained by voluntarily establishing themselves in the local community (taking an active part in the life of local clubs and associations; sometimes taking an interest in local politics; participating in the life of their district and laying down roots). At the same time, they fully understand the national aspects of urban transport through their relations with the national level of expertise (particularly the Urban Transport Research Centre) and through exchanges between the various bodies: GART; National Federation of Town Planning Agencies; UTP; ATEC. Working parties, conferences and publications also contribute to making these new local experts the ideal people to act as links with the experts at national level.

Finally, they are intermediaries between users and elected representatives. On the one hand, the new local experts do not confine themselves to certain roles, but willingly use their own experience as users (and sometimes as active members of associations). On the other hand, the methods used (door-to-door surveys, opinion polls, behavioural studies), which take into account all social strata, are aimed at taking into account the behaviour and needs of the user, thus relating the previous weight of traffic models to methodological practice. The new local experts wish to be considered as spokesmen for the users in discussions with local elected representatives. The latter have every interest in considering them as such, thus avoiding face-to-face discussions with the electors and with local pressure groups.

\subsubsection{Re-definition of the idea of public service}

The idea of public service is ingrained to such an extent in the public transport sector that it is referred to more or less explicitly in policy documents and methods studies. As defenders of the common good (given priority over the sum of special interests) in their position as government civil servants, the highways engineers use economic calculations to define the usefulness of a project to the community, using an approach based on rational argument. As defenders of local interests, the municipal engineers tend rather to consider that it is the duty of politicians to decide public service policy. The mayor decides for the good of the community. Permanently placed between the above two, the new local experts clearly see the ambiguity of the notion of common good, given the contradictions between local and national considerations, between public and private interests, etc. Their definition of public service is based on the relative situation of various social forces at a given time, taking into account the effect of transport policies. The notion of common good gives way to that of negotiated community interests. Moreover, it is because of their special position in the negotiating process that these experts claim to legitimately represent the views of the local people. They will threfore concentrate on the priority to be given to the minority methods of transport-public transport and also two-wheelers and pedestrians - with the aim of achieving a better balance in order to improve the whole system of travelling. In the same way, where public transport is concerned, they will try to find a compromise between satisfying the demand and keeping down the cost to the community as a whole. Our argument is summarized in table 3.

\section{The 1980s: diversified expertise at the service of local authorities and companies} 3.1. Institutional and conceptual development

\subsubsection{The institutional acceleration of decentralization}

The 1982/85 period was one of intense institutional change: 21 laws and more than 185 decrees concerned with decentralization. Among other changes, territorial 
Table 3. Public service as seen by the three groups of experts.

\begin{tabular}{|c|c|c|c|}
\hline & $\begin{array}{l}\text { National } \\
\text { experts }\end{array}$ & $\begin{array}{l}\text { Municipal } \\
\text { experts }\end{array}$ & $\begin{array}{l}\text { New local } \\
\text { experts }\end{array}$ \\
\hline Status & $\begin{array}{l}\text { Government civil } \\
\text { servants }\end{array}$ & $\begin{array}{l}\text { Local government } \\
\text { employees }\end{array}$ & $\begin{array}{l}\text { Contractual, public } \\
\text { or private sector }\end{array}$ \\
\hline Training & $\begin{array}{l}\text { Economics } \\
\text { Road and rail } \\
\text { techniques } \\
\text { Town planning }\end{array}$ & $\begin{array}{l}\text { Urban techniques. } \\
\text { Traffic engineering } \\
\text { Town planning }\end{array}$ & $\begin{array}{l}\text { Human sciences } \\
\text { Town planning } \\
\text { Technical }\end{array}$ \\
\hline $\begin{array}{l}\text { Territorial } \\
\text { involvement }\end{array}$ & Various levels & Municipal & Inter-community \\
\hline $\begin{array}{l}\text { Relations with } \\
\text { central } \\
\text { government }\end{array}$ & Strong & Weak & Strong \\
\hline $\begin{array}{l}\text { Professional } \\
\text { identity }\end{array}$ & Strong & Strong & Weak \\
\hline Local input & Low & High & Intermediate \\
\hline $\begin{array}{l}\text { Approach to } \\
\text { policy }\end{array}$ & Neutral & Familiar & Involved \\
\hline Priority of values & Common good & Local interests & Community interests \\
\hline $\begin{array}{l}\text { Working } \\
\text { approach }\end{array}$ & $\begin{array}{l}\text { Economic } \\
\text { calculation } \\
\text { 'Economic and } \\
\text { social efficiency' } \\
\text { (LOTI) }\end{array}$ & $\begin{array}{l}\text { Political choice of } \\
\text { local elected } \\
\text { representatives }\end{array}$ & $\begin{array}{l}\text { Social groups, } \\
\text { territories } \\
\text { 'Right to transport' } \\
\text { (LOTI) }\end{array}$ \\
\hline
\end{tabular}

responsibilities have been changed by giving local elected representatives the autonomy they demanded. Thus France began to modernize its local government structures, decades behind its Anglo-Saxon neighbours (the 36000 communes are still maintained!).

Although, prior to 1981, the organization of urban public transport, traffic movements, parking and town planning were to all practical purposes the responsibility of local authorities (whether alone or in association), they have now been given this responsibility by right, as well as being given powers of land-use and transport management.

The public organization of all types of transport in urban areas now involves several tiers of local government, among which the central government has shared the powers transferred (see table 4). Although decentralization marks the withdrawal of central government from local affairs, a movement already started during the previous decade, through the Law on the Future of Internal Transport (LOTI) of 1982 in the field with which we are concerned, it has nevertheless made up for previous gaps (see $\S 2.1)$ by recreating a unified body following a policy of consensus.

\subsubsection{The systematic and consensual policy of the LOTI}

The LOTI defines the system of transport in all the complexity of its intermodal components and its relations with the physical and socio-economic environment 
Table 4. Institutional changes in the public organization of urban travel.

\begin{tabular}{|c|c|c|}
\hline & Prior to decentralization & After decentralization \\
\hline $\begin{array}{l}\text { General law (for } \\
\text { information) }\end{array}$ & $\begin{array}{l}\text { Prior control by central } \\
\text { government of local authority } \\
\text { staff and actions } \\
\text { Definition by central } \\
\text { government of all types. of } \\
\text { technical standard and } \\
\text { procedure; equipment grants } \\
\text { Central government (via the } \\
\text { Prefect) control of } \\
\text { departmental and regional } \\
\text { assemblies }\end{array}$ & $\begin{array}{l}\text { Abolition of prior control; } \\
\text { subsequent check of legality, } \\
\text { with possibility of appeal } \\
\text { Simplified technical standards } \\
\text { and procedures: } \\
\quad \text { legal basis } \\
\text { national simplification } \\
\text { commission } \\
\text { Overall development grants } \\
\text { with national system of } \\
\text { allocation to local authorities } \\
\text { Compensation for transferred } \\
\text { powers }\end{array}$ \\
\hline $\begin{array}{l}\text { Breakdown of public } \\
\text { transport powers at } \\
\text { various local levels }\end{array}$ & $\begin{array}{l}\text { Mayors responsible for traffic } \\
\text { and parking matters } \\
\text { Organization of urban } \\
\text { transport } \\
\text { Town planning documents } \\
\text { prepared jointly with central } \\
\text { government } \\
\text { Land-use decisions } \\
\text { Local road maintenance and } \\
\text { layout (see Travel Plans) }\end{array}$ & $\begin{array}{l}\text { Renewal of FPT statutes } \\
\text { Partial transfer of central } \\
\text { government powers to local } \\
\text { authorities } \\
\text { Responsibility for preparation } \\
\text { of town planning documents } \\
\text { Preparation and application } \\
\text { of Urban Travel Plans by } \\
\text { competent authority for urban } \\
\text { transport organization (see } \\
\text { LOTI) }\end{array}$ \\
\hline Departments & $\begin{array}{l}\text { Departmental road } \\
\text { maintenance and layout } \\
\text { Establishment and } \\
\text { management of Departmental } \\
\text { Transport Authorities }\end{array}$ & $\begin{array}{l}\text { The same as before. } \\
\text { Organization of non-urban } \\
\text { passenger and school } \\
\text { transport excluding PDU (see } \\
\text { LOTI) }\end{array}$ \\
\hline Regions & $\begin{array}{l}\text { Regional development studies, } \\
\text { community facilities, } \\
\text { development aid for local } \\
\text { authorities (see roads; private } \\
\text { transport) }\end{array}$ & $\begin{array}{l}\text { Development planning } \\
\text { Organization of non-urban } \\
\text { passenger transport of } \\
\text { regional interest (see LOTI) }\end{array}$ \\
\hline Central & $\begin{array}{l}\text { Social, safety regulations; } \\
\text { technical checks (LOTI) } \\
\text { National road network } \\
\text { Railway (SNCF) }\end{array}$ & $\begin{array}{l}\text { Contractual partner of local } \\
\text { authorities (development of } \\
\text { public transport, road safety) }\end{array}$ \\
\hline
\end{tabular}

(particularly the town planning/transport interface and the social costs). The public management of this system calls for an overall policy associating direct and indirect partners around economically and socially effective objectives and in the form of renewed contractual relations. A key element in this policy must be the idea of the right to transport which would appear to be the answer to the already distant echo from the demonstrations of users in the Paris region in the 1970s, demanding priority for public transport and travel between home and work free of charge. The delays in granting this right would seem to make it somewhat ambivalent: on the one hand, affirmation of the right of users to 'travel in reasonable conditions of access, quality and price' and, on the other hand, a reminder that the level of satisfaction is limited by the 'cost to the 
community'. The LOTI therefore refers the various territorial authorities responsible for managing the transport system to the necessity for progressive introduction of this right, which will depend on the traditional choice between the ends and the means, with nevertheless two objectives to be borne in mind, as follows.

The priority to be given by the authorities to encouraging the use of public passenger transport, bearing in mind the need for 'complementarity' and 'fair competition' between the different methods of transport.

The right of users 'to be informed' of transport means and features. The right to travel free between home and work has not been instituted, but in the Paris area employers finance half their employees' carte orange price. Based on this policy and in spite of the simplified technical procedures mentioned above, the LOTI promotes Urban Travel Plans (PDUs) in urban areas, a new planning procedure under the responsibility of local authorities empowered to organize urban public transport (in most cases, ad hoc associations of urban and suburban authorities). Proceeding from the decentralized, contractual and democratic planning referred to in the Ninth Plan (1984-88), these PDUs define transport policy orientations, including traffic systems and parking in urban areas. The elected representatives of the various authorities included in the urban transport organization, the technicians and managers involved in the development of transport systems (town planning, traffic flow, public transport, parking, etc.) are called upon jointly to prepare action programmes aimed at 'more rational use of the private motor car... and the satisfactory insertion of pedestrians, twowheelers and public transport'.

The future of the urban transport system depends on this procedure as shown below.

\subsubsection{Prospects}

In a continuing period of slow economic growth, social and technological changes and the financial squeeze on public services in the 1980s, the government is encouraging the elected representatives of provincial towns to use the PDU procedure:

to stem the rise in social costs generated by urban sprawl, two-car families and the breaking up of traditional communities;

to ensure transition between the previous development of transport infrastructures and the increasing efficiency of public transport, as represented by automated operations, inter-network co-ordination, information technology, marketing, etc.; and

to intervene in the travel market in order to reduce the dependence on the private motor vehicle by encouraging public transport companies in the search for new clients, local pressure groups in favour of improving safety for pedestrians and cyclists, the media to become more aware of the various methods of urban travel, etc.

These prospects, together with the new representation of the transport sector, as affirmed by the LOTI and introduced by the decentralization measures, can place in perspective the roles played on the occasion of a PDU. Returning to our initial argument, we shall attempt to explain this process which updates relations between the technical and political authorities. 


\subsection{Towards new know-how?}

The aims given for the LOTI assign a dual objective to the PDUs: to integrate all factors relating to travel in the urban area by relating them to all problems of urban life and development and by encouraging better use of space and energy ... and also to assist in the necessary promotion of public transport through improved co-ordination between the transport and road authorities and the traffic authorities.

Application by the local authorities of the objectives of the legislator would appear to be made as follows:

towards the objective of improved co-ordination of powers relating to road maintenance and traffic flow, which corresponds to updating the local power configurations and injecting technical expertise in the increasingly complex decision-making process; and

towards the objective of adapting the choice of travel organization to developments in social habits and urbanization, which corresponds to searching for alliances between local transport managers and their partners in various social organizations-property investors, companies, schools, trade associations, district associations, socio-cultural groups, etc.

In addition, the necessity for social communication inherent in PDU procedures (public inquiry) would seen to change completely the established relations between transport authorities, other local authorities and the general public.

\subsubsection{Local takeover of the central government standard}

The slight difference in meaning caused by the LOTI using the term 'travel' instead of 'transport' (see Transport Plans for the 1960s and 1970s) or 'traffic' (see Traffic Plans for the 1970s and 1980s) does not appear to be a matter of chance. Travel would appear to include the various aspects of the action of going from one place to another: reason, point of departure/destination, method used, etc. It is therefore not simply a question of infrastructures for any particular method but, once again, a system of social and technical organization.

Elected representatives, technicians and urban public transport managers appear to have taken full advantage of the overall approach of PDUs to extend their room for manoeuvre in the local decision-making process. The elected representatives responsible for urban public transport use the PDU to encourage co-operation between the elected representatives responsible for traffic flow, road maintenance and town planning. Conversely, some of these, particularly in the less well-equipped surrounding communities, use the PDU to release a few development files in abeyance - ring roads, the laying out of open spaces to improve the environment, etc. This means that, for some elected representatives, the PDU can serve as a springboard to stardom on the local political stage, as a result of the institutional changes and by changes following the 1983 municipal elections. Their opportunities to negotiate at the different levels of government (departmental, regional and national) have been increased significantly.

In this context, the role of technical expertise is confirmed as one of mediation and of the management of interfaces: parking and public transport; urban developments and traffic flow; urban and non-urban transport, etc. Technical control of these is indispensable as a means of affirming local policies and forms part of urban transport management concerned by the national plan for the 1980s, with the development of the GART. In this way, the technical services concerned by the diagnosis of travel problems 
when applying PDUs, which identify interference and 'malfunction' between the various elements of the transport system, provide the elected representativives involved in the PDUs with conceptual control of the local partners and produce the consensual standards required to affirm local policies. For all that, these elected representatives involved with the PDUs generally have no direct control over the various technical structures respectively concerning urban development, road systems, traffic, etc. The technical organization of public transport is the responsibility of the operating companies, which are relatively independent.

This means that these elected representatives use the PDU to introduce a restructuring process outside the 1 cal technical organizations, by recruitment of PDU mission heads under their direct control, and by use of multi-discipline research structures such as the Town Planning Agencies. There may be plurality-therefore conflict-in the expert evaluation. These recent structural movements shed light on the future of technical expertise. As an example, the profile of PDU mission heads is likely to ally the two types of engineering previously referred to ('hard' transport techniques, 'soft' social relations techniques). In the larger towns with well-developed technical structures, the first type of profile would seem to be a necessary condition for recruitment, due to the social prestige associated with the Grandes Ecoles and the Corps of Engineers, prestige or technical reputation necessary for the interorganization co-ordination function (Suleiman 1978).

The Town Planning Agencies, whose technical competence is based more on the horizontal capacity to understand urban problems than on their operational intervention, appear to consider the PDUs as particularly valuable tools at a time when overall planning is continually having to give way to local management concerns. Their local role should become stronger if, by concentrating on their capacity to analyse the prospective local and inter-community urban processes, they develop a system of providing elected representatives with technical advice on questions of area and daily management. These two types of structural change, accelerated by the PDUs, mean that technical expertise in the transport field is developing in accordance with a dual process of horizontal services and involvement in existing area management.

\subsubsection{Partners looking for alliances}

In an urban environment, the objectives of economic and social efficiency recommended by the LOTI are likely to update the prospects of local authority intervention upstream and downstream of the transport system and in events generating travel; in other words, involvements in space, in time and in the urban way of life.

The PDUs already in being allow for the intervention of transport in the organization of some institutions. For example, the staggering of school hours in favour of economy and with the aim of improving rush-hour transport services, and the organization of property developments linked to the completion of changeover complexes, i.e. integrated transport stations for trains, coaches, buses, and taxis. These examples involve several local partners, e.g. school authorities, teachers, parents, pupils, etc., where the first is concerned, and Chambers of Commerce and Industry, property developers, landowners, etc., where the second is concerned.

By their involvement in these complex affairs, elected representatives playing leading roles in the PDU build up a capital of social relations which they can reinvest in order to influence technical and political choices and to develop their local or even national reputations. This strategy of institutional alliances outside the strict field of 
transport involves PDU technicians $\dagger$ in political and economic areas where they do not have complete technical control. Remaining with the examples already mentioned, it is not without risk for their promoters to mount experiments in staggered hours which greatly affect the daily lives and opinions of the general public and which are difficult to control. In the same way, questions of marketing the major and complex developments concerning changeover centres include a certain risk for the investments of companies and households.

Under these conditions, the technical function first plays its role of bringing the partners together in a progressive process of setting up new alliances between transport authorities and other social institutions. The technicians are partially transformed into public relations men in order to strengthen these alliances through new practices, by the organization of research trips, etc. These experimental and innovative approaches require the technician to concentrate more on negotiation and discussion of what the situation involves than on the methodical and rational valuation of objective data.

For many technicians, the present make-up of PDUs is accelerating this transformation of know-how, already well under way through the process of social innovation which accompanied the revival of urban public transport-socially targeted promotion campaigns, and design and composition of networks taking into account the requirements of the social communication media. It is worth noting the probable introduction in provincial towns of experiments in on-board cultural entertainment (video equipment on board vehicles and at waiting points, interactive information units, data communications or data-processing, live entertainment on transport premises, etc.), which are already well under way in the Paris area.

\subsubsection{Feed-back strategy}

The public inquiry included in the PDU procedure seems to be understood by the elected representatives and technicians as a means of conversing with the population and its representatives, offering the dual advantage of obtaining agreement on the proposed operations and infrastructures and encouraging rational behaviour. However, the locally elected representatives are directly in the line of fire of local pressure groups (shopkeepers, district associations, etc.) for most projects and developments (mixed pedestrian/bus streets, parking charges, the introduction of a bus route, change in the direction of traffic flow, etc.).

The marketing techniques often developed by public transport operators are used by the PDU technicians to promote communication plans concerning travel policy objectives.

Despite their visible demonstration of inaccessible authority and of aggressive modernity, transport systems are nevertheless also instruments of adaptation to life in towns, of social freedom and intercourse. It is this positive acceptance of the social role of transport and of the mobility offered that the PDU managers appear to emphasize in their efforts to communicate, at the same time identifying themselves with the modern cultural model of the upward-moving middle classes closely concerned with urban management. A liberal management style, showing awareness of the different ways of life and considering media innovation is the principal factor in socio-political management.

$\dagger$ In the table of PDU political commissions, the various technical experts are referred to by the elected representatives as 'technicians'. We therefore use this term, which more generally describes technical expertise, rather than a particular professional qualification. 
The first media products from the PDUs effectively appear to copy the marketing experience of the main institutions or companies (e.g. the RATP), concentrating on a feed-back strategy: soothing messages - indirect, playful and convivial-are the most efficient way of obtaining the sought-after changes of behaviour. Strongly on the side of the user, the first media themes used appear to be aimed at simplifying life in towns ('Make life easier - take the bus'; 'How to use your town'), but also taking advantage of its organic structure ('Travel is living'; 'Urban transport-a town's lifeblood') and of the possibility to discover its hidden secrets and riches ('The network's secrets'; '... offers you the keys to the city').

\section{Conclusions}

The technical planning process for urban travel systems in France in the 1970s appears to have been marked and carried along by the appearance of a characteristic profile of local expertise. A profile determined by the context of public transport revival in towns, widening of local regulations concerning social relations and the appearance of ever more complex techniques of organizational and systems management. A profile implying as much the control of flow statistics as that of the growing universe of social representations and that of the system of involvement in local decision-making and actions. This profile progressively appeared in socio-professional circles made up mainly of the upward-moving middle classes partially involved in the public management of local affairs. During the 1980s, wide-ranging institutional changes (an increase in the rate of decentralization) and falling public investments in the provinces appears to have altered the compact make-up of this socio-professional class.

The mobility between the technical services of the government, local authorities and public transport operators, which had resulted in the specific multi-discipline nature of expertise, is now encountering several obstacles:

rigidity of the many professional statuses, not concerned by the institutional decentralization (moveover, it would appear that the latter is accentuating the break-up of career structures); and

contradiction of demographic origin between the increased demand for promotion and the limited openings, whence some marginal move by staff out of the urban transport planning/management field.

An initial examination of current PDU activities would appear to indicate several ways in which local expertise could evolve, as follows.

(1) The closest possible local political supervision of projects, implying considerable inter-organization co-ordination (in the case of major towns, in particular); the very mobile spoil-system based on a network of reputable technicians, generally from the elite engineering schools.

(2) Limited upward movement by multi-discipline technical organizations, of the Town Planning Agency type, the national technical capacity of which should become stronger, particularly in the forecasting and communication functions.

(3) Inclusion in the network of public transport management companies, whose role as social and technological innovators is strengthened by the development of internal and external data-processing systems (centralized orders, aids to design, operation and information) and by the growth of on-board cultural entertainment activities. 
(4) Establishment within the existing frameworks of the traditional technical services of local authorities or central government, which have a more administrative function, and the sub-contracting role of which should be strengthened.

In the last case, as in the first, it is worth noting the prospects offered by the new nonurban transport organizing powers transferred to the departmental and regional authorities. As this paper has concentrated on urban matters, no assessment has been made of the opportunity this presents.

Contrary to other sectors of urban management (e.g. the relative decline of spaceuse planning), the strengthened role of locally elected representatives responsible for the development of public transport evident since the first introduction of the versement-transport (2.1.2) and the development of the GART, seems to have encouraged and strengthened co-operation between the various local experts, and we would expect this to develop further.

The historical firmness of these relations must come as much from the growing social powers of the local authority, legitimated by the decentralization measures, as from the introduction of technological and socio-cultural innovations into the public organization of urban travel.

\section{Foreign summaries}

L'analyse des transformations du milieu professionnel de l'expertise en organisation des transports urbains contribue à la connaissance du processus et de l'idéologie de la planification en France. En effet, dans ce pays, les années soixante-dix ont été caractérisées par l'activation de la planification urbaine et corrélativement par le renouveau des transports publics. Une forme originale d'évaluation publique des actions de restructuration des réseaux et de la ville en a résulté, sous l'impulsion notamment d'experts médiateurs des enjeux socio-économiques de la décision locale. Cette expertise, à double obédience, centrale et locale, a puisé ses fondements culturels, tant dans la rationalité technocratique de la planification économique de l'aprèsguerre, que dans le mouvement social libertaire et écologique des années soixante-dix. L'idéologie de la planification démocratique, décentralisée et contractuelle dominant la conjoncture des années soixante-dix a été institutionnalisée dans les années quatre-vingts par la procédure des Plans de Déplacements Urbains. Mais celle-ci est mise en oeuvre dans un contexte de dérèglementation latente, qui révèle ainsi la relative hétérogénéité du milieu d'experts considéré.

Die Beschäftigung mit Änderungen im professionellen Wirkungsfeld der Experten im städtischen Verkehr wirft ein bezeichnendes Licht auf Entwicklung und Planungsziele in Frankreich.

Die siebziger Jahre waren gekennzeichnet durch aktive Stadtplanung, verbunden mit einer Erneuerung des öffentlichen Verkehrs. Neue Wege zur Bewertung der Erneuerung von Netzen und Städten wurden unter dem Einfluß von Experten beschritten, die sich als Mittler zwischen sozialen und ökonomischen Faktoren, die den örtlichen Entscheidungsablauf beeinflussen, verstanden.

Diese Experten standen beruflich in zweifacher Bindung, einer zentralen und einer lokalen. Ihrern kulturellen Hintergrund bildete sowohl der technokratische Rationalismus der Wirtschaftsplanung in der direkten Nachkriegszeit als auch die libertären und socioökologischen Bewegungen der achtziger Jahre. Die Theorie der demokratischen, dezentralisierten und vertraglich geregelten Planung, die während der siebziger Jahre Gestalt annahm, wurden in den achtziger Jahren institutionalisiert in Form von städtischen Verkehrsplänen. Dieses geschah allderdings im Zusammenhang mit einer Deregulierung (Liberalisierung) und zeigt die Doppeldeutigkeit im Wirkungsfeld der Experten. 
El análisis de cambios en el ambiente profesional de los especialistas en transporte urbano, da ciertas luces sobre la evolución y objetivos de la planificación en Francia. La década de los 70 se caracterizó por una planificación urbana activa, combinada con un renacimiento del transporte público. Se desarrollaron nuevas formas de evaluar la restructuración de redes y poblados, bajo la influencia de especialistas que actuaron como intermediarios en relación a algunos de los factores sociales y económicos que inciden en la toma de decisiones a nivel local. Estos especialistas tenian lealtades profesionales tanto a nivel local como central. Ellos forjaron su acervo cultural no sólo tomando elementos del racionalismo technocrático proveniente de la planificación económica de la post-guerra, sino que extrayendo ideas de los movimientos sociales, libertarios y ecológicos, que han tenido su máxima expresión en la década de los 80 . Así, la teoría de una planificación democrática, descentralizada y contractual, que tomó forma durante la década anterior, fue institucionalizada en la forma de Planes de Transporte Urbano en esta década. Sin embargo, esto ha ocurrido en el contexto de la desregulación, lo que ilustra cuan ambiguo es el medio ambiente de estos expertos.

\section{References}

LASSAVE, P., 1987, L'expérience des plans de déplacements urbains (1983-86) (Bagneux: Centre d'Etudes des Transports Urbains, Ministère des Transports).

OFFNER, J. M., 1987, L'expertise locale en transports urbains des années soixante-dix, l'ère des nouveaux technocrates, Rapport de recherche INRETS no. 22, Institut National de Recherche sur les Transports et leur Sécurité.

Suleiman, E. N., 1978, Elites in French society: The Politics of Survival (Princeton: Princeton University Press).

\section{Editorial suggestions for further reading}

BENwELl, M., 1982, Social research in transport-the French experience as seen from the U.K., Transport and Road Research Laboratory, SR689, pp. 63-73.

This paper begins by attempting to set up a framework within which it may be possible to compare recent research activities in France, Germany and the United Kingdom in social aspects of transport. It is argued that research activity can only be understood at the product of a particular economic, social and institutional environment in which it takes place. The paper then discusses this environment as it applies to France, and then goes on to discuss the kind of research currently or recently in process in France.

Flockton, C. H., 1984, France: Ambitious Gaullist designs and constrained socialist plans, Built Environment, 10 (2), pp. 132-144.

In France, the change from growth to stagnation or decline has diminished the credibility of long-term strategic planning, and even the purpose of long-term planning has been questioned. While the present decentralist policies provide scope for local and regional planning, the national strategic planning function no longer seems appropriate. This paper discusses the evolution and the uncertainties facing strategic planning in France.

HoueE, M., 1984, New local and regional planning procedures for public transport, Planning Transport Research and Computation, Volume P252.

The decentralization policy being implemented in France today means considerable changes in non-urban public transport planning and management at 
regional and local level. This paper examines the new powers of the regions and departments in public transport and their legal and financial means of action. It also analyses the relevant matters under debate in the preparation of the IXth national plan, the lessons to be drawn from the way the new policy has been implemented, and the early results of this policy. The 'Loi d'orientation des transports interieurs' (orientation law for inland transport), enacted in December 1982, gives the regions a major role in rail transport, and the departments in road passenger transport. The new law specifies the means by which the regions can develop a network of regional interest and stipulates the licensing conversion rules for non-urban road passenger traffic. The law of 22 nd July 1983 covers the transfer of school bus organization to the departments. The experience of several regions and departments is described.

(Author)

SCHABERT, T., 1985, The decentralisation and the new urban policy in France, Urban Law and Policy, 7 (1), pp. 57-74.

France is in the middle of decentralizing administrative and government responsibilities. New political life is emerging at a local level and is taking root in newly restored cities and revitalized neighbourhoods. This article analyses the new urban policy and decentralization detailing their origins, legal formulation and implementation. The author also discusses their historical, political and social significance.

(Author)

Simpson, B. J., 1987, Planning and Public Transport in Great Britain, France and West Germany (London: Longman), p. 171.

This book examines the relationships between planning and transport in three EEC countries. The focus of the general introductory section is on the planning and legislative framework together with a section that attempts to highlight similarities and differences in approach. The bulk of the book consists of a series of case studies on individual cities with Lyon being the French example.

See also: (1987) Eity Centre Planning and Public Transport (Wokingham: Van Nostrand). 